\title{
THE PERENNIAL PENSTEMON: VARIATION IN DEFENSIVE CHEMISTRY ACROSS YEARS, POPULATIONS, AND TISSUES
}

\author{
Caitlin A. Kelly and M. Deane Bowers \\ Department of Ecology and Evolutionary Biology and \\ University of Colorado Museum of Natural History, University of Colorado Boulder \\ UCB 334, Boulder, CO 80309, USA \\ Email: caitlin.a.kelly@,colorado.edu
}

Tel: 631-902-8003 
Abstract - Plants produce a variety of secondary metabolites that function as a defense against their natural enemies. Production of these secondary metabolites is genetically controlled, but is also phenotypically plastic and varies in response to both biotic and abiotic factors. Therefore, plant species may vary widely in their chemical defenses and such variation can be evident at temporal, spatial and tissue levels. Focusing on the chemical defenses of a native Colorado wildflower, Penstemon virgatus, we assessed the variation in iridoid glycoside (IG) content across two non-consecutive growing seasons, six natural populations and three tissue types: leaves, stems and flowers. Our results indicate that $P$. virgatus plants contain high concentrations of IGs (mean $=23.36 \%$ dry weight of leaves) and that IGs were differentially allocated among tissue types. Leaves contained the highest concentration of IGs, which varied quantitatively between sampling years, among plant populations, and plant parts. We also quantified leaf herbivore damage at all six populations but we found very little herbivore damage. Our study indicates that the IG concentrations of $P$. virgatus plants are both spatially and temporally variable. Furthermore, the high concentrations of secondary metabolites combined with the low levels of damage suggest that these plants are well defended against generalist herbivores.

Key Words - Iridoid glycosides, Catalpol, Scutellarioside, Penstemon virgatus, Herbivory, Chemical defenses 


\section{INTRODUCTION}

As a result of evolutionary interactions with other organisms and plastic responses to the environment, plant populations exhibit extensive variation in secondary metabolite content. Intraspecific variation in plant secondary metabolites depends on several factors (reviewed in Moore et al. 2014), including but not limited to: ontogeny (Quintero and Bowers 2011), genotype (e.g. Berenbaum et al. 1986; Gouyon et al. 1983), the presence of herbivores (Rios et al. 2008) and various components of the abiotic environment, such as water and nutrient availability (Waterman and Mole 1989). Since chemical phenotypes have significant ecological implications for multiple trophic levels, it is important to understand the relative contributions of the factors that influence phenotype in natural populations. This study focuses on three potential sources of variation in secondary metabolites in a long-lived herbaceous perennial: inter-annual (across years), location (among geographically distinct populations) and plant tissue type.

By definition, herbaceous perennial plants have a life cycle lasting longer than one year, with many perennials living for several years (Harper 1977). Although perennials are ubiquitous, there are surprisingly few data on the temporal variation in plant quality (i.e. variation across years) of natural populations of long-lived herbaceous plants. Many longer-term studies of plant quality examined woody plants (e.g. Laitinen et al. 2005; Nichols-Orians 1991; Scogings et al. 2004), or were conducted as greenhouse experiments (e.g. Gols et al. 2007). For long-lived perennials, abiotic factors, such as light and temperature, and biotic factors, such as the presence of pathogens and herbivores, may change from year to year. This has the potential to alter both primary and secondary metabolism As a result, each generation of a given herbivore species may experience a different host plant landscape. In addition, many herbivores have life cycles that span more than one year; for example, many checkerspot butterflies (Melitaeini) have oviposition and early larval development in one year, an over-winter diapause, and complete 
their development the following year (Murphy et al. 2004). Thus, ovipositing females and early instar larvae may interact with host plants that are chemically different than the host plants on which post-diapause larvae depend. An herbivore may find a host plant palatable one year, but unpalatable the next. For herbivores that have the ability to sequester plant secondary metabolites, their own palatability to predators may vary along with chemical content of the host plant. Thus, secondary metabolite variation has implications for interactions between higher trophic levels (e.g. Gols et al. 2008).

Chemical variation may also be evident at the population level. This variation can be expressed at quite different spatial scales. Populations separated by only a few kilometers can show wide variation in the make-up of their secondary metabolite phenotype (e.g. Moyes et al. 2000; Newton et al. 2009a, b), whereas populations separated by over $1000 \mathrm{~km}$ may not show any significant variation (Gols et al. 2009). Such variation, and the factors underlying its control, in plant secondary chemistry can be particularly important for highly mobile herbivores that may interact with several populations of a given plant species. Much of this spatial variation can be attributed to local adaptation or phenotypic plasticity of genotypes in response to changes in resources availability (reviewed in Moore et al. 2014). There is ample support that secondary metabolites are influenced by their environment, but not always in predictable ways (Endara and Coley 2011).

Within a single population, significant variation can be observed among as well as among different tissue types within individual plants. Secondary metabolites are not evenly distributed across plant tissues or organs. The optimal defense theory (ODT; also known as the tissue value hypothesis) hypothesizes that the allocation of defensive compounds within a plant is a function of tissue or organ value in terms of fitness, because secondary metabolites are costly to produce (McCall and Fordyce 2010; Stamp 2003). Under the ODT, flowers are sometimes predicted to be 
more valuable than leaves because they are more directly related to sexual reproduction (Strauss et al. 2004). Similarly, new leaves are expected to have higher levels of secondary compounds than older leaves (Krischik and Denno 1983; McKey 1979). Such variation within an individual plant can significantly affect the fitness of that plant's associated herbivores (Mody et al. 2007). Some herbivores feed on multiple plant parts. For example, Calophasia lunula feeds on the leaves and flowers of Dalmatian toadflax, Linaria dalmatica (Plantaginaceae) and Utetheisa ornatrix feeds on the leaves and seeds of Crotolaria spectabilis (Fabaceae)). Such herbivores may experience substantial differences in both the quantity and composition of defensive chemicals in these different tissues (Ferro et al. 2006; Martins et al. 2015; Sourakov 2015; Wilson et al. 2005).

Our goal is to describe potential sources of chemical variation in a long-lived perennial plant, in order to better understand the chemical landscape in which herbivores interact with this host plant. We examined intraspecific variation in the secondary metabolite content of the perennial Penstemon virgatus A. Gray (Plantaginaceae) as a function of year, population and tissue type. Penstemon virgatus is chemically defended by iridoid glycosides (IGs), a group of cyclopentanoid monoterpene-derived compounds found in over 50 plant families (Boros and Stermitz 1990). We describe how the concentrations of the major IGs found in P. virgatus, catalpol and scutellarioside, differ among and within a) two growing seasons, b) six Colorado populations, and c) three plant tissues, namely leaves, flowers and stems. We also quantified herbivore damage in the field to assess its relationship with plant IG content.

\section{METHODS AND MATERIALS}

Study Species. Plants of the genus Penstemon are long-lived herbaceous perennials native to North America, including higher elevation locations throughout Colorado. Penstemon 
virgatus grows in rocky or sandy soils in mountain meadows throughout Colorado and other southwestern states (Quintero and Bowers 2013; Shonle et al. 2004). P. virgatus, also known as the upright blue beardtongue, features narrow leaves, tall stems and long inflorescences with several small to medium purple flowers that bloom from June to August (Crosswhite 1967; Quintero and Bowers 2013). Previous research found two major IGs in P. virgatus: catalpol and scutellarioside-II (henceforth referred to as scutellarioside; L'Empereur and Stermitz 1990b). Documented herbivores include Euphydryas anicia, Polydryas arachnae, Polydryas minuta (all family Nymphalidae) and Meris alticola (Geometridae) (L'Empereur and Stermitz 1990b; Robinson et al. 2002; Stermitz et al. 1988).

Collection Procedure. We visited six known locations of $P$. virgatus throughout the Colorado Front Range and eastern Rocky Mountains (Table 1) in July 2011 and July 2013. In both years, at each location, $15-20$ individual flowering plants were collected. Although $P$. virgatus is a long-lived perennial, individual plants may not return the following year, so we sampled different individual plants each sampling year. Plants were haphazardly chosen at each site, but were only considered if they were in bloom with no fruits. If an individual plant had multiple flowering stalks, only one stalk was removed. In 2013, herbivory was quantified for those plants that were collected (see below). After collection, samples were oven dried at $50^{\circ} \mathrm{C}$ (Gardner and Stermitz 1988; Small et al. 2010, Bowers and Stamp 1992) and then divided into three tissue types (leaves, flowers and stems), which were extracted and analyzed separately for iridoid glycosides (see below). Permits were obtained to collect plants within Rocky Mountain National Park (ROMO-2011-SCI-0055, ROMO-2013-SCI-0046) and Eldorado Canyon State Park. 
Herbivory. Herbivory data were only collected in the 2013 season. Prior to harvesting individual plants for chemical analysis, we quantified herbivore damage in the field using a method similar to that of Stamp and Bowers (1996). The length of each leaf of every plant sampled was measured to the nearest millimeter and then visually examined for evidence of herbivore damage. The amount of damage on each leaf was categorized as: $0,1-5,6-10,11-25$, $26-50 \%$ of leaf tissue missing. As there was never more than $50 \%$ of leaf tissue missing due to herbivory, we did not need to include higher damage categories. The midpoint of each damage category $(3 \%, 8 \%$, etc.) was multiplied by leaf length and the values for all leaves on a plant were added to provide an index of herbivory, or the total amount eaten for each plant. This index was then divided by the sum of the leaf lengths to calculate the proportion of leaf tissue eaten per plant. Crescent Meadows was the only population where herbivory was directly observed. The IG specialist Euphydryas anicia was seen using $P$. virgatus as a host plant at this location.

Chemical Analyses. We quantified the concentration of the IGs catalpol and scutellarioside via gas chromatography (Bowers and Collinge 1992; Bowers and Stamp 1992; Gardner and Stermitz 1988; Kelly and Bowers 2016). Individual plants were separated into leaves, flowers and stems. Each tissue from each individual plant was then ground to a fine powder with a mortar and pestle. A subsample of $25 \mathrm{mg}$ from each sample was extracted overnight in $5 \mathrm{ml}$ of methanol. The solid material was removed by filtration, and the extract evaporated to dryness. One milliliter of an internal standard, phenyl $\beta$-D-glucopyranoside dissolved in water (PBG, $0.500 \mathrm{mg}$ ), was added to each sample. Then, the sample was partitioned three times between water and ether at a ratio of four parts water to three parts ether. The ether fraction, which contains lipophilic substances, was discarded. The water fraction, containing primarily the iridoid glycosides and sugars, was evaporated to dryness. Each sample was then re- 
dissolved in one milliliter of methanol for at least eight hours. A $0.1 \mathrm{ml}$ aliquot from each sample was derivatized using Tri-Sil Z (Thermo Fisher Scientific) and $1 \mu \mathrm{l}$ was injected into an Agilent 7890A gas chromatograph equipped with a flame ionization detector (FID) and Agilent DB-1 column (Bowers and Collinge 1992; Fajer et al. 1992; Gardner and Stermitz 1988). The GC was calibrated with a standard containing known quantities of PBG (Sigma Aldrich), catalpol (isolated and purified in the Bowers lab) and scutellarioside (obtained from P. Molgaard). Data were processed with Agilent ChemStation software (version A.03.34).

Statistical Analyses. Iridoid glycoside (IG) concentrations were linearized with a logit transformation to meet assumptions of normality. Given that catalpol and scutellarioside were correlated (Pearson's correlation coefficient $=0.28 ; P<0.0001$ ), we used a three-way multivariate analysis of variance (MANOVA) to assess variation in IG concentration due to plant part (leaves, flowers or stems), population and year. When the MANOVA detected significant effects, we followed up with univariate, ANOVAs for each dependent variable (catalpol and scutellarioside). We used repeated-measures ANOVAs for analyses that included tissue type (the repeated measure) as a main effect. For all univariate ANOVAs, Tukey's post hoc multiple comparisons tests were used to examine pairwise differences among groups when significant differences were detected. We used a Kruskal-Wallis test to compare herbivore damage across all six populations and also to compare herbivory at the Crescent Meadows population against the other five populations, as Crescent Meadows was the only population where we directly observed herbivory. We assessed the relationship between herbivory and leaf chemistry for the 2013 season with Pearson product-moment correlations for all populations combined and for Crescent Meadows alone. All statistical analyses were performed in R version 3.1.2. 


\section{RESULTS}

In this study, a total of 243 individual plants were sampled across six populations and two years. The average total iridoid glycoside concentration (catalpol and scutellarioside) of leaves was $23.36 \%$ dry weight $( \pm 0.53 \mathrm{SE})$. Leaves had over 4.5 times more scutellarioside than catalpol. The average total dry weight of IG in flowers was $16.36 \%( \pm 0.43 \mathrm{SE})$, comprised of approximately equal concentrations of catalpol and scutellarioside. Leaves contained over two times more scutellarioside than flowers (scutellarioside: mean leaves $=19.45 \%$ dry weight \pm 0.49 SE; mean flowers $=8.49 \%$ dry weigh $\pm 0.39 \mathrm{SE}$ ); yet, flowers had two times more catalpol than leaves (catalpol: mean flowers $=7.87 \%$ dry weight $\pm 0.18 \mathrm{SE}$; mean leaves $=3.91 \%$ dry weight $\pm 0.14 \mathrm{SE})$. Stems contained comparatively low concentrations of total IGs (mean $=$ $4.73 \%$ dry weight $\pm 0.35 \mathrm{SE})$.

Results of the MANOVA indicated a significant three-way interaction between plant part, population and year $\left(\right.$ Wilks $\left.^{\prime} \lambda=0.878 ; F_{20,1382}=4.65, P<0.001\right)$. Furthermore, all main effects and two-way interactions were significant $(P<0.01$ for all). Based on the results of this MANOVA, we proceeded with separate univariate ANOVAs for catalpol and scutellarioside. Three-way ANOVAs, with tissue type as the repeated measure, revealed significant three-way interactions between tissue type, population and year for both scutellarioside $\left(F_{10,689}=6.54, P<\right.$ $0.001)$ and catalpol $\left(F_{10,689}=3.05, P<0.001\right.$; Table 2$)$. Univariate ANOVAs for each tissue type indicated that catalpol and scutellarioside varied in their response to the effects of population, year, and the interaction of these two factors (Table 3; Figure 1). For all three tissues, there was a significant population by year interaction for scutellarioside. Flowers were the only tissue that showed a significant population by year interaction for catalpol. There was a significant effect of population for catalpol in leaves and stems.

There was a marginally significant difference in the amount of herbivore damage among 
the six populations (Kruskal-Wallis $\chi^{2}=10.03, \mathrm{df}=5, P=0.0743$; Figure 2). Overall, there was very little herbivore damage on $P$. virgatus (mean $=2.61 \%$ of leaf damaged $\pm 0.25 \mathrm{SE}$ ). Although there was no overall effect of population on herbivore damage, a comparison of damage at the Crescent Meadows population with that of the other populations showed that Crescent Meadows had significantly higher levels of herbivory (Kruskal-Wallis $\chi^{2}=6.27, \mathrm{df}=1$, $P=0.0123)$. There was no significant correlation between herbivore damage and leaf chemistry for all populations combined (Total IGs: Pearson's correlation coefficient $=-0.0685, P=0.467$; Scutellarioside only: Pearson's correlation coefficient $=-0.0416, P=0.659$; Catalpol only: Pearson's correlation coefficient $=-0.110, P=0.240$ ), nor for the Crescent Meadows population alone (Total IGs: Pearson's correlation coefficient $=0.277, P=0.238$; Scutellarioside only: Pearson's correlation coefficient $=0.233, P=0.324$; Catalpol only: Pearson's correlation coefficient $=0.320, P=0.169)$.

\section{DISCUSSION}

Few studies, if any, have looked at long-lived, herbaceous perennials in the same populations in different years, although some previous studies have examined variation in plant secondary metabolites across different populations and over development (e.g. Brenes-Arguedas and Coley 2005; Cirak et al. 2012; Fortuna et al. 2014; Jamieson and Bowers 2010; Quintero and Bowers 2012). Here, we show that catalpol and scutellarioside concentrations in P. virgatus vary due to tissue type, population and year. Consistent with other studies (Alba et al. 2013; Cirak et al. 2012; Darrow and Bowers 1997; Jamieson and Bowers 2010), we found significant variation between different populations. Our results indicate that $P$. virgatus contains quite high levels of iridoid glycosides, as compared to previous studies with IG-defended plants. For example, Jamieson and Bowers (2010) found a maximum total IG concentration of $17.4 \%$ dry weight in 
Linaria dalmatica and Darrow and Bowers (1997) found 12\% dry weight total IGs in Plantago lanceolata. We also found that different plant tissues vary in the relative proportion of catalpol to scutellarioside. Leaves contained over two-fold more scutellarioside than catalpol, although flowers had two-fold more catalpol. We observed the specialist herbivore Euphydryas anicia using $P$. virgatus as a host plant at Crescent Meadows and plants at that location had the most herbivore damage, although the amounts were still quite low. Other potential generalist herbivores, such as grasshoppers, were present at all populations but there was little evidence of such herbivores feeding on those plants.

Our results indicate that $P$. virgatus plants are both spatially and temporally variable in their IG concentration. Plant demographic studies have monitored long-term variation in plant population dynamics (Harper and White 1974; Roach and Gampe 2004), but they have not investigated whether chemical defenses change from one year to the next. In general, investigations of variation in defensive chemistry in herbaceous plants have focused on shortterm temporal variation, typically examining changes within a single season (Alba et al. 2013; Brenes-Arguedas and Coley 2005; Cirak et al. 2012; Darrow and Bowers 1997; Jamieson and Bowers 2010; Quintero and Bowers 2012). Longer-term studies, over multiple growing seasons, on the chemical defenses of herbaceous perennial plants are lacking. Penstemon virgatus has a multi-year life cycle; thus variation in IG content over a several year time span could have important consequences for the local herbivore community. Future research should also consider monitoring variation in the defensive chemistry of individual perennial plants over multiple years, as such variation would be ecologically relevant to herbivores with multi-year life spans.

Leaves contained the highest total concentration of IGs and were particularly rich in scutellarioside. These high concentrations are unprecedented for adult Penstemon virgatus plants (L'Empereur and Stermitz 1989; L'Empereur and Stermitz 1990b), but are generally consistent 
with previous data on juvenile P. virgatus plants (approx. 19\% dry weight total IGs; Quintero and Bowers 2013). Flowers, however, were comparatively high in catalpol. Often, the concentration of catalpol in flowers far exceeded that in leaves. Meanwhile, stems were generally IG poor. According to the Optimal Defense Theory (McCall and Fordyce 2010; Stamp 2003), reproductive tissues are likely to be higher in constitutive defenses, as they are an essential element of plant fitness. Support for this theory can be found in the Brassicaceae, as flowers can be more concentrated in glucosinolates than leaves (Smallegange et al. 2007; Strauss et al. 2004). However, it is unknown whether our chemical data represent constitutive defenses, inducible defenses or a mixture of both. Leaves were clearly the tissue type with the highest IG concentration, and though they are not reproductive tissues, they are an important component of plant fitness as they are the main photosynthetic organs. Flowers had lower IG concentrations than leaves overall, but perhaps higher proportions of catalpol carry an ecological significance. We do not yet understand the relative effectiveness of catalpol and scutellarioside as deterrents or toxins to generalist herbivores; thus it is possible one compound is more effective than the other (Bowers and Puttick 1988; Puttick and Bowers 1988). Some studies have found distributions of defensive compounds like those found in the leaves and flowers of $P$. virgatus (e.g. Cirak et al. 2012), while others have found that the secondary metabolite content of leaves is similar to that of flowers (Jamieson and Bowers 2010). Furthermore, plant parts may differ in their $\beta$-glucosidases, which play an important role in the activation of IGs (Pankoke et al. 2013).

The high concentrations of IGs in $P$. virgatus suggest that it is well defended against generalist herbivores, a notion supported by our observation that herbivory was limited in the populations we examined. Earlier research found that $P$. virgatus is unpalatable to generalist insect herbivores and can reduce generalist larval performance (Kelly and Bowers 2016). However, given the observed variation among populations and across years, it is possible that in 
some years, levels of IGs are low enough that generalists can use $P$. virgatus as a host plant. We did not observe any specialist herbivores, with the exception of the checkerspot, Euphydryas anicia, at the Crescent Meadows population. Previous accounts found checkerspots at the Michigan Hill population in 2007 (pers. comm. with C. Quintero), but we found no evidence of checkerspots at that location in either year. Euphydryas anicia was observed feeding and ovipositing on $P$. virgatus at Crescent Meadows in several years, but has been documented to prefer P. glaber at that location (Kelly and Bowers 2016).

We found no correlation between the IG concentration of leaves and the amount of herbivore damage for all populations. This was unexpected given the high concentrations of IG founds in leaves and the significant variation of IGs across the six populations. Crescent Meadows is the only population where herbivores were directly observed using $P$. virgatus as a host plant, but there was no correlation between IG concentrations and herbivory when that population was analyzed separately. The low levels of herbivory (less than $1 \%$ in five of six populations) that we observed may be the consequence of environmental factors or plant secondary metabolites other than IGs, such as the phenyl propanoid glycoside verbacoside (L'Empereur and Stermtiz 1990b). Alternatively, the significant temporal variation in IG concentration may be the result of a bet hedging strategy for this perennial plant (see Adler and Karban 1994; Moore et al. 2014). Herbivory can be subject to temporal variation as well. Some generalists, such as mountain pine beetles (Safranyik and Carroll 2006) or locusts (Uvarov 1977), demonstrate eruptive life cycle patterns. In such life cycles, population densities are low for extended periods of time and then intermittently rise to high densities (Wallin and Raffa 2004). In low-herbivory years, the baseline IG concentration may be sufficient to protect plants from herbivore damage. However, in high-herbivory years only plants with higher concentrations of IGs may survive. It is possible that we sampled low-herbivory years and thus 
the selective pressures for such variable and high concentrations of IGs were not evident.

In summary, our study demonstrates that secondary metabolites can vary significantly between years, across populations and within individual plants. Such adaptation has important implications for communities of herbivores, and, in particular, the specialist herbivores that use these plants as hosts. This variation may exert selective pressure on herbivores to successfully navigate a heterogeneous landscape. Consequently, herbivore performance will vary and, in turn, affect higher trophic levels. While we have some understand of population and tissue level variation on several species, multi-year research examining variation in secondary metabolites of perennial herbaceous plants is lacking. We recommend that future studies focus on temporal sources of variation in these defensive chemicals.

Acknowledgments: We thank Farah Abdelmawla, Michael Belazis, Hadley Hanson, Jason Hong, Quinn Langsfeld, Gift Pornsawan Poopat and Kristin White for field and laboratory assistance. We gratefully acknowledge Carolina Quintero, the members of the Bowers lab and Zachary Mullen for valuable feedback on experimental design and statistical analysis. We also thank P. Molgaard (University of Copenhagen) for providing standards of scutellarioside. This work was supported by grants from the Undergraduate Research Opportunity Program (to MDB), the Department of Ecology and Evolutionary Biology at the University of Colorado, Boulder (to CAK), the John W. Marr Fund in Plant Ecology (to CAK), the Hazel Schmoll Award (to CAK) and the William H. Burt Award (to CAK). 


\section{REFERENCES}

Adler FR, Karban R (1994) Defended fortresses or moving targets? Another model of inducible defenses inspired by military metaphors. Am Nat 144(5):813-832

Alba C, Prioreschi R, Quintero C (2013) Population and leaf-level variation of iridoid glycosides in the invasive weed Verbascum thapsus L (common mullein): implications for herbivory by generalist insects. Chemoecology 23(2):83-92

Berenbaum MR, Zangerl AR, Nitao JK (1986) Constraints on chemical coevolution: wild parsnips and the parsnip webworm. Evolution 40(6):1215-1228

Boros CA, Stermitz FR (1990) Iridoids An updated review Part I. J Nat Prod 53:1055-1147

Bowers MD, Collinge SK (1992) Fate of iridoid glycosides in different life stages of the buckeye Junonia coenia (Lepidoptera Nymphalidae). J Chem Ecol 18:817-831

Bowers MD, Puttick GM (1988) Response of generalist and specialist insects to qualitative allelochemical variation. J Chem Ecol 14:319-334

Bowers MD, Stamp NE (1992) Chemical variation with and between individuals of Plantago laceolata. J Chem Ecol 18:989-995

Bowers MD, Stamp NE (1993) Effects of plant age genotype and herbivory on Plantago performance and chemistry. Ecology 74:1778-1791

Brenes-Arguedas T, Coley PD (2005) Phenotypic variation and spatial structure of secondary chemistry in a natural population of a tropical tree species. Oikos 108:410-420

Cirak C, Radusiene J, Stanius Z, Camas N, Caliskan O, Serhat Odobas M (2012) Secondary metabolites of Hypericum orientale L growing in Turkey: variation among populations and plant parts. Acta Physiol Plant 34:1313-1320

Crosswhite FS (1967) Revision of Penstemon Section Habroanthus (Scrophulariaceae) III: Series Virgati. Am Midl Nat 77:28-41 
Darrow K, Bowers MD (1997) Phenological and population variation in iridoid glycosides of Plantago lanceolata (Plantaginaceae). Biochem Syst Ecol 25:1-11

Endara MJ, Coley PD (2011) The resource availability hypothesis revisited: a meta-analysis. Funct Ecol 25:389-398

Fajer ED, Bowers MD, Bazzaz FA (1992) The effect of nutrients and enriched $\mathrm{CO}_{2}$ environments on production of carbon-based allelochemicals in Plantago - a test of the carbon nutrient balance hypothesis. Am Nat 140:707-723

Ferro VG, Guimarães PR, Trigo JR (2006) Why do larvae of Utetheisa ornatrix penetrate and feed in pods of Crotalaria species? Larval performance vs chemical and physical constraints. Entomol Exp Appl 121(1):23-29

Fortuna TM, Eckert S, Harvey JA, Vet LE, Müller C, Gols R (2014) Variation in plant defences among populations of a range-expanding plant: consequences for trophic interactions. New Phytol 204(4):989-999

Gardner DR, Stermitz FR (1988) Host plant utilization and iridoid glycoside sequestration by Euphydryas anicia (Lepidoptera Nymphalidae) J Chem Ecol 14:2147-2168

Gols R, Raaijmakers CE, van Dam NM, Dicke M, Bukovinszky T, Harvey JA (2007) Temporal changes affect plant chemistry and tritrophic interactions. Basic Appl Ecol 8:421-433

Gols R, Wagenaar R, Bukovinszky T, van Dam NM, Dicke M, Bullock JM, and Harvey JA (2008) Genetic variation in defense chemistry in wild cabbages affects herbivores and their endoparasitoids. Ecology 89:1616-1626

Gols R, van Dam NM, Raaijmakers CE, Dicke M, and Harvey JA (2009) Are population differences in plant quality reflected in the preference and performance of two endoparasitoid wasps? Oikos 118:733-743 
Gouyon PH, Fort PH, Caraux G (1983) Selection of seedlings of Thymus vulgaris by grazing slugs. J Ecol 73:299-306

Harper JL (1977) Population biology of plants. Academic Press, London

Jamieson MA, Bowers MD (2010) Iridoid glycoside variation in the invasive plant Dalmatian toadflax Linaria dalmatica (Plantaginaceae) and sequestration by the biological control agent Calophasia lunula. J Chem Ecol 36:70-79

Kelly CA, Bowers MD (2016) Preference and performance of generalist and specialist herbivores on chemically defended host plants. Exol Entomol 41(3):308-316

Krischik VA, Denno RF (1983) Individual population and geographic patterns in plant defense. In: Denno RF, McClure MS (eds) Variable plants and herbivores in natural and managed systems. Academic Press, New York, pp 463-512

Laitinen ML, Julkunen-Tiitto R, Tahvanainen J, Heinonen J, Rousi M (2005) Variation in birch (Betula pendula) shoot secondary chemistry due to genotype environment and ontogeny. J Chem Ecol $31: 697-717$

L'Empereur KM (1989) Iridoid glycoside and pyrrolizidine alkaloid sequestration by specialist Lepidoptera. Dissertation, Colorado State University

L’Empereur KM, Stermitz FR (1990a) Iridoid glycoside content of Euphydryas anicia (Lepidoptera: Nymphalidae) and its major host plant Besseya plantaginea (Scrophulariaceae) at a high plains Colorado site. J Chem Ecol 16:187-197

L'Empereur KM, Stermitz FR (1990b) Iridoid glycoside metabolism and sequestration by Poladryas minuta (Lepidoptera: Nymphalidae) feeding on Penstemon virgatus (Scrophulariaceae). J Chem Ecol 16:1495-1506 
Martins CHZ, Cunha BP, Solferini VN, Trigo JR (2015) Feeding on host plants with different concentrations and structures of pyrrolizidine alkaloids impacts the chemical-defense effectiveness of a specialist herbivore. PLoS One 10:e141480

McCall AC, Fordyce JA (2010) Can optimal defence theory be used to predict the distribution of plant chemical defences? J Ecol 98(5):985-992

McKey D (1979) The distribution of secondary compounds within plants In: Rosenthal GA, Janzen DH (eds) Herbivores: Their interactions with secondary plant metabolites. Academic Press, New York, pp 55-133

Mody K, Unsicker SB, Linsenmair KE (2007) Fitness related diet-mixing by intrapsecific hostplant-switching of specialist insect herbivores. Ecology 88(4):1012-1020

Moore BD, Andrew RL, Külheim C, and Foley WJ (2014) Explaining intraspecific diversity in plant secondary metabolites in an ecological context. New Phytol 201(3):733-750

Moyes CL, Collin HA, Britton G, Raybould AF (2000) Glucosinolates and differential herbivory in wild populations of Brassica oleracea. J Chem Ecol 26(11):2625-2641

Murphy DD, Wahlberg N, Hanski I, Ehrlich PR (2004) Introducing checkerspots: taxonomy and ecology. In Ehrlich PR, Hanski I (eds) On the wings of checkerspots: a model system for population biology. Oxford University Press. New York, pp 17-33

Newton EL, Bullock JM, Hodgson DJ (2009a) Bottom-up effects of glucosinolate variation on aphid colony dynamics in wild cabbage populations. Ecol Entomol 34:614-623

Newton EL, Bullock JM, Hodgson DJ (2009b) Glucosinolate polymorphism in wild cabbage (Brassica oleracea) influences the structure of herbivore communities. Oecologia 160:63-76

Nichols-Orians CM (1991) Environmentally induced differences in plant traits: consequences for susceptibility to a leaf-cutter ant. Ecology 72:1609-1623 
Pankoke H, Buschmann T, Müller C (2013) Role of plant $\beta$-glucosidases in the dual defense system of iridoid glycosides and their hydrolyzing enzymes in Plantago lanceolata and Plantago major. Phytochemistry 94:99-107

Puttick GM, Bowers MD (1988) Effect of qualitative and quantitative variation in allelochemicals on a generalist insect: Iridoid glycosides and the southern armyworm. J Chem Ecol 14:335-351

Quintero C, Bowers MD (2011) Plant induced defenses depend more on plant age than previous history of damage: implications for plant-herbivore interactions. J Chem Ecol 37:9921001

Quintero C, Bowers MD (2012) Changes in plant chemical defences and nutritional quality as a function of ontogeny in Plantago lanceolata (Plantaginaceae). Oecologia 168:471-481

Quintero C, Bowers MD (2013) Effects of insect herbivory on induced chemical defences and compensation during early plant development in Penstemon virgatus. Ann Bot-London 112:661-669

R Core Team (2016) R: A language and environment for statistical computing. R Foundation for Statistical Computing, Vienna, https://www.R-project.org/

Rios RS, Marquis RJ, Flunker JC (2008) Population variation in plant traits associated with ant attraction and herbivory in Chamaecrista fasciculata (Fabaceae). Oecologia 156:577-588

Robinson GS, Ackery PR, Kitching IJ, Beccaloni GW, Hernandez LM (2002) Hostplants of the moth and butterfly caterpillars of America North of Mexico. Mem Am Entomol Inst $69: 1-824$

Safranyik L, Carroll AL (2006) The biology and epidemiology of the mountain pine beetle in lodgepole pine forests. In: Safranyik L, Wilson B (eds) The Mountain Pine Beetle: A 
Synthesis of Its Biology Management and Impacts on Lodgepole Pine. Natural Resources Canada, Canadian Forest Service, Pacific Forestry Centre, Victoria, pp 3-66

Scogings PF, Dziba LE, Gordon IJ (2004) Leaf chemistry of woody plants in relation to season canopy retention and goat browsing in a semiarid subtropical savanna. Austral Ecol 29:278-286

Shonle I, Klett JE, Vickerman LG (2004) Native Herbaceous Perennials for Colorado Landscapes. Colorado State University Cooperative Extension. http://extension.colostate.edu/topic-areas/yard-garden/native-herbaceous-perennials-forcolorado-landscapes-7-242/. Accessed 20 December 2016

Small EE, Larson KM, Braun JJ (2010) Sensing vegetation growth with reflected GPS signals. Geophys Res Lett 37: L12401

Smallegange RC, van Loon JJA, Blatt SE, Harvey JA, Agerbirk N, Dicke M (2007) Flower vs. leaf feeding by Pieris brassicae: Glucosinolate-rich flower tissues are preferred and sustain higher growth rate. J Chem Ecol 33:1831-1844

Sourakov A (2015) You are what you eat: native versus exotic Crotalaria species (Fabaceae) as host plants of the Ornate Bella Moth Utetheisa ornatrix (Lepidoptera: Erebidae: Arctiinae). J Nat Hist 49:2397-2415

Stamp NE (2003) Theory of plant defensive level: example of process and pitfalls in development of ecological theory. Oikos 102:672-678

Stamp NE, Bowers MD (1996) Consequences for plantain chemistry and growth when herbivores are attacked by predators. Ecology 77:535-549

Stermitz FR, Gardner DR, McFarland N (1988) Iridoid glycoside sequestration by two aposematic Penstemon-feeding geometrid larvae. J Chem Ecol 14:435-441 
Strauss SY, Irwin RE, Lambrix VM (2004) Optimal defence theory and flower petal colour predict variation in the secondary chemistry of wild radish. J Ecol 92:132-141

Uvarov B (1977) Grasshoppers and locusts. A Handbook of General Acridology. Vol 2. Behaviour, ecology, biogeography, population dynamics. Centre for Overseas Pest Research, London

Wallin KF, Raffa KF (2004) Feedback between individual host selection behavior and population dynamics in an eruptive herbivore. Ecol Monogr 74:101-116

Waterman PG, Mole S (1989) Extrinsic factors influencing production of secondary metabolites in plants. In: Bernays EA (ed) Insect-Plant Interactions. CRC Press, Boca Raton pp 107134

Wilson LM, Sing SE, Piper GL, Hansen RW, De Clerck-Floate R, MacKinnon DK, C Randall (2005) Biology and Biological Control of Dalmatian and Yellow Toadflax. USDA Forest Service, FHTET-05-13 


\section{FIGURE CAPTIONS}

Fig 1 The mean concentration of (a) scutellarioside and (b) catalpol between sampling years for each population and tissue type (leaves, flowers and stems). In each population, lines connect the 2011 means to the 2013 means for each tissue type. Means \pm SE. Population abbreviations, in order of increasing elevation: CM - Crescent Meadows ( $n=23$ in 2011, $n=20$ in 2013); CWD Calwood Education Center ( $\mathrm{n}=21$ in 2011, $\mathrm{n}=20$ in 2013); LRTH - Lumpy Ridge Trail Head $(\mathrm{n}=15$ in 2011, $\mathrm{n}=20$ in 2013); CL - Cub Lake $(\mathrm{n}=22$ in 2011, $\mathrm{n}=20$ in 2013); CHLK Chalk Lake Campground ( $\mathrm{n}=23$ in 2011, $\mathrm{n}=20$ in 2013); MIH - Michigan Hill ( $\mathrm{n}=24$ in 2011, $\mathrm{n}=15$ in 2013).

Fig 2 Leaf consumption by herbivores on Penstemon virgatus across six Colorado populations (n $=20$ plants for each population): Crescent Meadows (CM), Calwood Education Center (CWD), Michigan Hill (MIH), Cub Lake (CL), Lumpy Ridge Trailhead (LRTH) and Chalk Lake Campground (CHLK). Means $\pm \mathrm{SE}$. 
Table 1 The six Penstemon virgatus sampling populations in Colorado, USA

\begin{tabular}{|c|c|c|c|c|}
\hline Population & Abbr. & Location & Coordinates & Elevation (m) \\
\hline Crescent Meadows & $\mathrm{CM}$ & $\begin{array}{l}\text { Boulder, CO - Eldorado } \\
\text { Canyon State Park }\end{array}$ & $\begin{array}{c}39.931^{\circ} \mathrm{N} \\
105.338^{\circ} \mathrm{W}\end{array}$ & 2258 \\
\hline Calwood Education Center & CAL & Jamestown, CO & $\begin{array}{c}40.150^{\circ} \mathrm{N} \\
105.389^{\circ} \mathrm{W}\end{array}$ & 2371 \\
\hline Lumpy Ridge Trailhead & LRTH & $\begin{array}{l}\text { Estes Park, CO - Rocky } \\
\text { Mountain National Park }\end{array}$ & $\begin{array}{c}40.401^{\circ} \mathrm{N} \\
105.520^{\circ} \mathrm{W}\end{array}$ & 2415 \\
\hline Cub Lake & CUB & $\begin{array}{l}\text { Estes Park, CO - Rocky } \\
\text { Mountain National Park }\end{array}$ & $\begin{array}{c}40.357^{\circ} \mathrm{N} \\
105.619^{\circ} \mathrm{W}\end{array}$ & 2481 \\
\hline Chalk Lake Campground & CLC & Nathrop, CO & $\begin{array}{c}38.713^{\circ} \mathrm{N} \\
106.232^{\circ} \mathrm{W}\end{array}$ & 2670 \\
\hline Michigan Hill & MIH & Jefferson, $\mathrm{CO}$ & $\begin{array}{c}39.363^{\circ} \mathrm{N} \\
105.837^{\circ} \mathrm{W}\end{array}$ & 2931 \\
\hline
\end{tabular}


Table 2 Summary of three-way, repeated measures ANOVAs that tested the effects of tissue type, population and year and their interactions on the iridoid glycoside content of Penstemon virgatus. The IGs catalpol and scutellarioside were measured as a concentration (\% dry weight)

\begin{tabular}{lrrrrr}
\hline & \multicolumn{3}{c}{ Catalpol } & \multicolumn{2}{c}{ Scutellarioside } \\
& $d f$ & $F$ & \multicolumn{1}{c}{$P$} & \multicolumn{1}{c}{$F$} & \multicolumn{1}{c}{$P$} \\
\hline Tissue & 2 & 83.75 & $<\mathbf{0 . 0 0 1}$ & 87.41 & $<\mathbf{0 . 0 0 1}$ \\
Population & 5 & 19.05 & $<\mathbf{0 . 0 0 1}$ & 15.57 & $<\mathbf{0 . 0 0 1}$ \\
Year & 1 & 0.18 & 0.67 & 0.62 & 0.43 \\
Tissue x Population & 10 & 3.36 & $<\mathbf{0 . 0 0 1}$ & 3.96 & $<\mathbf{0 . 0 0 1}$ \\
Tissue x Year & 2 & 2.76 & 0.10 & 2.29 & 0.064 \\
Year x Population & 5 & 1.26 & $<\mathbf{0 . 0 0 1}$ & 5.48 & 0.28 \\
Year x Population x Tissue & 10 & 3.05 & $<\mathbf{0 . 0 0 1}$ & 6.54 & $<\mathbf{0 . 0 0 1}$ \\
Error & 689 & & & & \\
\hline
\end{tabular}


Table 3 Summary of two-way ANOVAs comparing IG content for each tissue type across six Colorado populations and two sampling years. The IGs catalpol and scutellarioside were measured as a concentration ( $\%$ dry weight)

\begin{tabular}{|c|c|c|c|c|c|c|c|c|c|c|c|c|c|c|c|}
\hline & \multicolumn{5}{|c|}{ Leaves } & \multicolumn{5}{|c|}{ Flowers } & \multicolumn{5}{|c|}{ Stems } \\
\hline & \multirow[b]{2}{*}{$d f$} & \multicolumn{2}{|c|}{ Catalpol } & \multicolumn{2}{|c|}{ Scutell. } & \multirow[b]{2}{*}{$d f$} & \multicolumn{2}{|c|}{ Catalpol } & \multicolumn{2}{|c|}{ Scutell. } & \multicolumn{4}{|c|}{ Catalpol } & \multirow{2}{*}{$\begin{array}{c}\text { Scutell. } \\
P\end{array}$} \\
\hline & & $F$ & $P$ & $F$ & $P$ & & $F$ & $P$ & $F$ & $P$ & $d f$ & $F$ & $P$ & $F$ & \\
\hline Population & 1 & 4.70 & $<0.001$ & 2.04 & 0.074 & 1 & 3.57 & 0.0039 & 5.37 & $<0.001$ & 1 & 15.06 & $<0.001$ & 16.68 & $<0.001$ \\
\hline Year & 5 & 0.003 & 0.95 & 0.45 & 0.50 & 5 & 0.33 & 0.57 & 14.34 & $<0.001$ & 5 & 0.44 & 0.51 & 0.00 & 0.99 \\
\hline $\begin{array}{l}\text { Year } \mathrm{x} \\
\text { Population }\end{array}$ & 5 & 0.79 & 0.56 & 2.33 & 0.043 & 5 & 5.48 & $<0.001$ & 6.73 & $<0.001$ & 5 & 2.005 & 0.079 & 7.24 & $<0.001$ \\
\hline Error & 233 & & & & & 230 & & & & & 229 & & & & \\
\hline
\end{tabular}




\section{FIGURE 1}

A

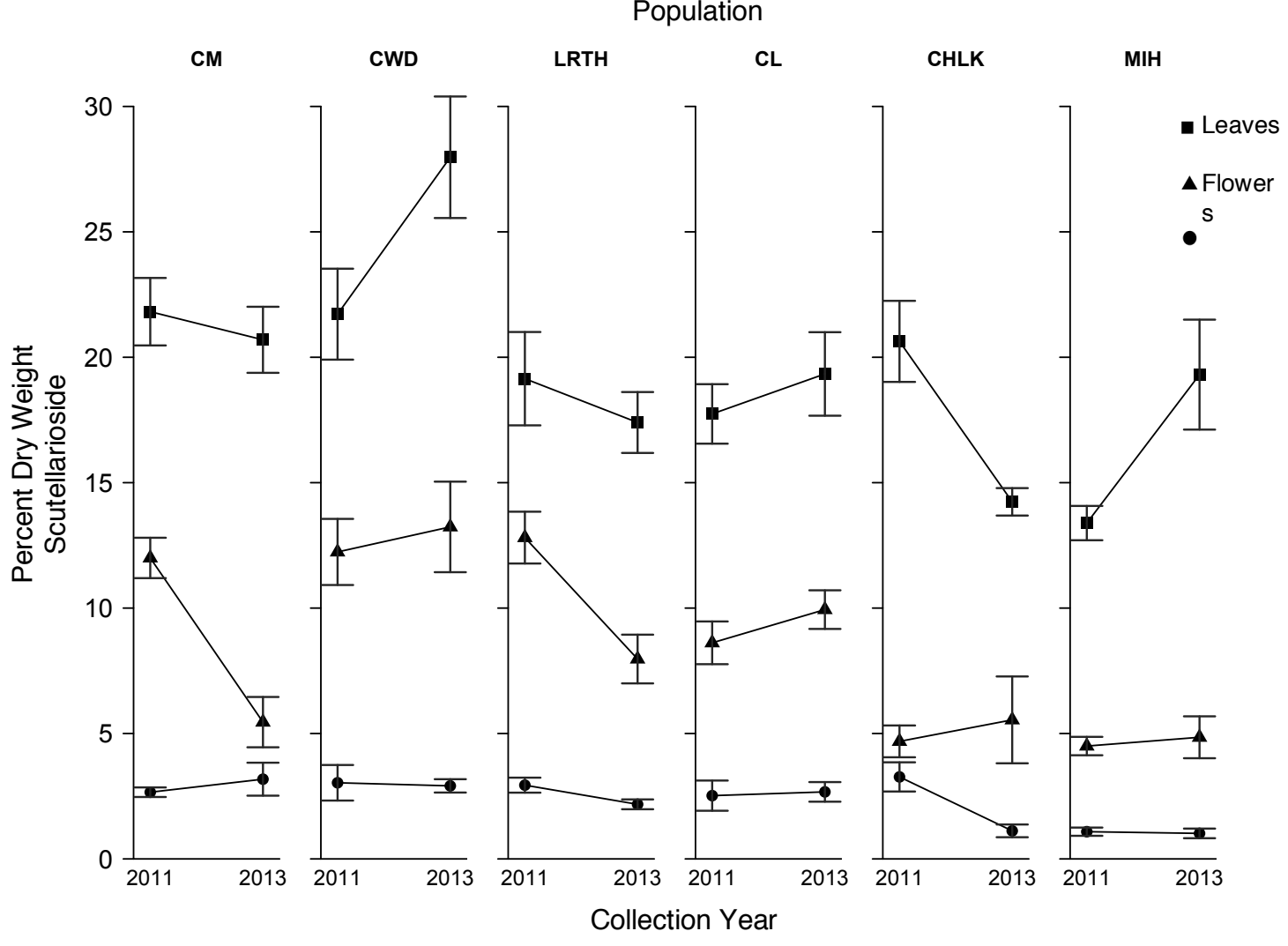

B

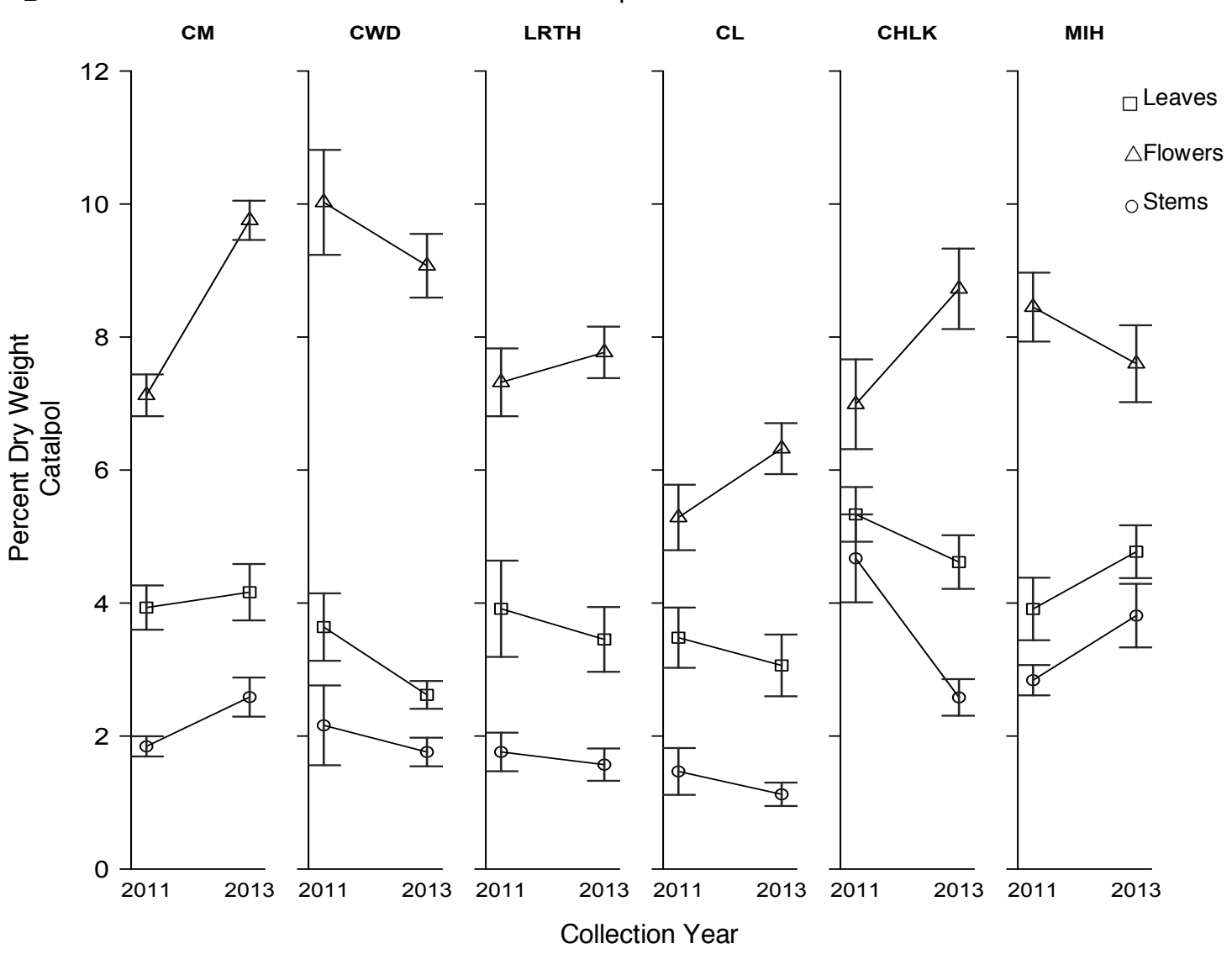


FIGURE 2

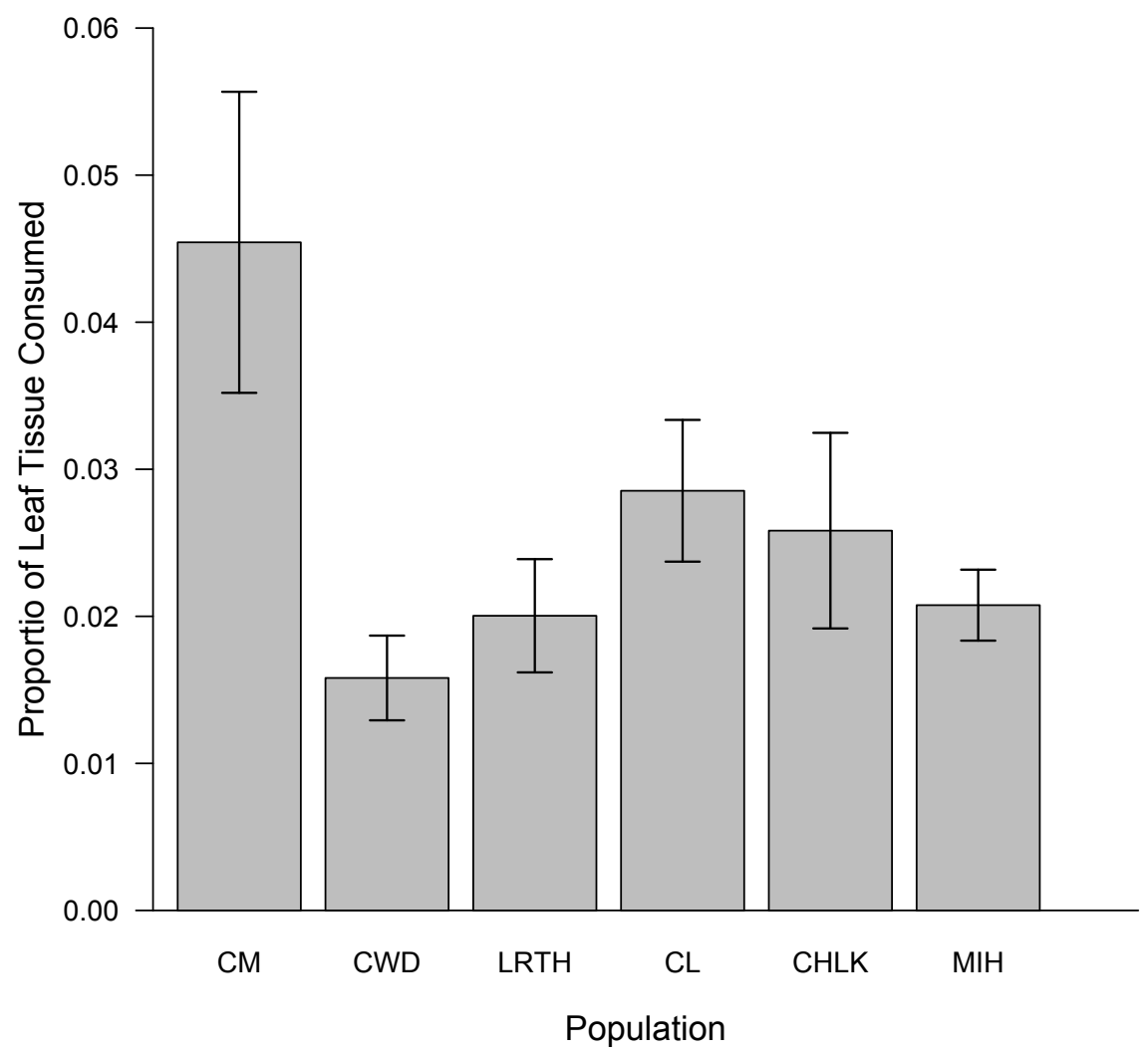

